\title{
Analytic Methods for Quality Control of Scientific Publications Part VII: Providing High-Quality Academic English-OnLine English
}

\author{
Ilia Brondz ${ }^{*} \oplus$, Paul Harrison ${ }^{2}$ \\ ${ }^{1}$ Drug Control and Drug Discovery Institute (NDCDDI), Ski, Norway \\ ${ }^{2}$ OnLine English, Hobart, Australia \\ Email: ^ilia.brondz@gmail.com, management@oleng.com.au
}

How to cite this paper: Brondz, I. and Harrison, P. (2020) Analytic Methods for Quality Control of Scientific Publications Part VII: Providing High-Quality Academic English-OnLine English. International Journal of Analytical Mass Spectrometry and Chromatography, 8, 1-6.

https://doi.org/10.4236/ijamsc.2020.81001

Received: February 26, 2020

Accepted: March 27, 2020

Published: March 30, 2020

Copyright $\odot 2020$ by author(s) and Scientific Research Publishing Inc. This work is licensed under the Creative Commons Attribution-NonCommercial International License (CC BY-NC 4.0). http://creativecommons.org/licenses/by-nc/4.0/ (c) (i) (\$) Open Access

\begin{abstract}
Correct grammar, coherent structure, fluent expression, and clear presentation are necessities for academic literature in the sciences and humanities. For scientific papers, these parameters are important to authors as well as to readers, especially for scientists who wish to understand the theory or to replicate the results. Today, most scientific and humanities journals are published in English. There are journals in Chinese, German, Hindi, Russian and other languages; however, for international use in science, business, and computer hardware and software, English is the dominant language. English is also used in diplomacy and for all kinds of international communications by people who have various other native languages. In this paper, we will present one of the leading international providers of high-quality academic English-OnLine English (OLE) and some of the functions of this service will be described.
\end{abstract}

\section{Keywords}

Scientific English, Academic Language, OnLine English, Functional Services

\section{Introduction}

From the time when God confounded a single common language [1] to prevent people from pursuing common enterprises and accomplishing audacious projects such as the Tower of Babel, humankind has sought to achieve understanding between different groups of people who use different languages.

In ancient times in Mesopotamia and the Middle East, the most commonly used language was Aramaic; later, Greek gained dominance (especially after the 
adaptation of the Phoenician alphabet), and when Rome spread its Empire over most of Europe, North Africa and the Middle East, Latin prevailed as the language of communication, although Greek was used among the highly educated and the elite, and in international affairs. The adoption of the Phoenician script was a foundation for all European alphabets. For more than a thousand years, Latin was the exclusive language of the Catholic Church, the Bible, and Christian liturgies.

The prophet Muhammad understood the power of consolidation of peoples through a common language, and he introduced Arabic as the only authorized language for the Koran, hadith, and prayers. Today, more than 1.5 milliard people regularly use Arabic to pray. In the Middle Ages, through Spanish conquest, most of the Iberian Peninsula, and in Europe, the southern part of France and Italy, were freed from Arabic invasion, and the influence of the Arabic language was weakened. Through Spanish conquest, in most of South America, many islands in the Caribbean and parts of the Netherlands, the Old Spanish language became dominant, and more than 500 million people now speak the present-day Spanish language, with the Old Spanish language persisting only among Sephardic Jews in Turkey.

During the Renaissance, French became the common language in some parts of Africa and some islands in the Caribbean and the Indian Ocean in addition to France itself. Today, it is also the official language for postal authorities worldwide. Chinese, Hindi, and Urdu also have significant use.

However, in recent times, with explosive developments in scientific literature, exchange of scientific ideas, commercial business, cinema, and especially computerization, the English language has become the most widely used and understood by educated people in countries around the world. In Norway, virtually every indigenous person speaks English, and all students in universities and high schools must have a good knowledge of English from gymnasium.

However, English has many subdivisions: British (UK) English is somewhat different from American (US) English. As Editor-in-Chief of this journal, I come into contact with texts written by scientists from the Philippines, India, Malaysia, and Russia in which the language is difficult to understand, despite being in English. The usage of terminology, punctuation, and articles is idiosyncratic, and sentence structures always have a touch of the author's native language. English is used by people who have very different native languages, cultures, professions, education, and customs. Because of this, many native words from other languages are adopted and anglicized, from well-known expressions like "OK" to even slang from criminal societies. English is under linguistic pressure and is increasingly prone to the influence of slang and other informal usages.

In scientific presentations, consistent usage of formal English, whether American or British, remains very important.

This paper is the latest in a series that was started in the American Journal of Analytical Chemistry, 2012, 3, pp. 443-447, https://doi:10.4236/ajac.2012.36058 under the title Analytical Methods in Quality Control of Scientific Publications, 
which has been written as "a response to personal appeal by David JW Lane the Editor-in-Chief of Research and Reports in Biodiversity Studies to support and promote the international author standards as developed by COPE for authors and editors-in-chief posted to me April 3rd 2012 (International standards for editors and authors http://www.dovepress.com/rrbscope.t9699812)" [2]. Several papers on the same theme have been written [3] [4] [5] [6] [7] and devoted to the improvement of communication between scientists [8] [9].

The main aim of the series is the improvement of the content of scientific publications by preventing falsified and plagiaristic publications, and by disclosing the names of their authors, editors, and promotors. This is especially important in the branches of science in which repetition of experiments is crucial, such as chemistry (organic, analytic, and synthetic), medicine, pharmacy, physics, and many others, or in circumstances where health or life itself is at stake. However, contact between researchers is also a valuable activity made possible by the wide publication of new information.

Clear, correct, fluent, and well-organized text written in proper English must be in every paper and available to every researcher. It is the goal of this publication.

\section{OnLine English}

OnLine English (OLE) is the original online English editing service and the leading global provider of first-class academic editing for all the sciences, humanities, and professions. For authors who have English as a second language, OLE offers superior English editing of all texts in the scientific, humanities and business fields (Figure 1).

OLE's CEO Dr. Nigel Spence states: "We bring together Australian scientific and linguistic expertise to provide English correction and improvement for authors whose native language is not English. We have been helping scientists, researchers, and professionals from all over the world to publish in high-impact journals since 1995” (Figure 2).

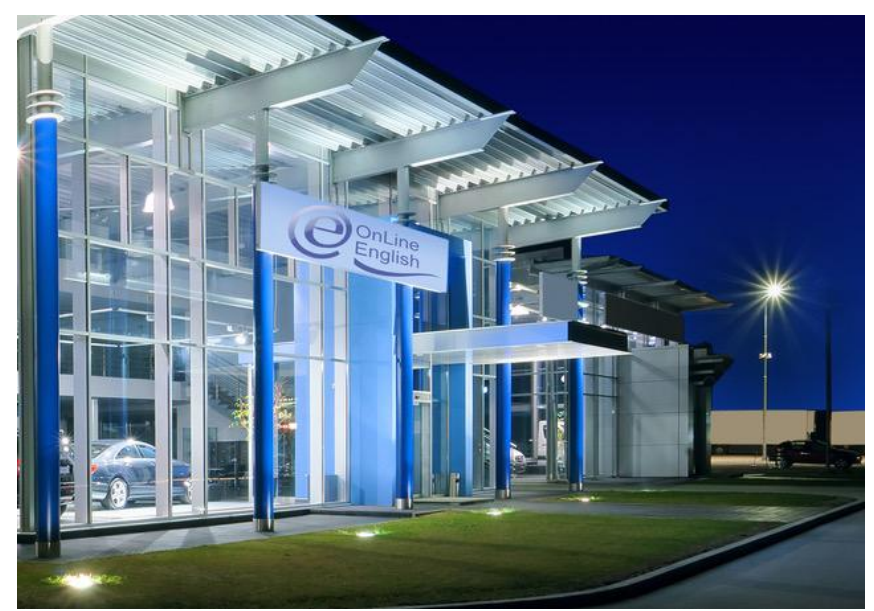

Figure 1. OLE office. 


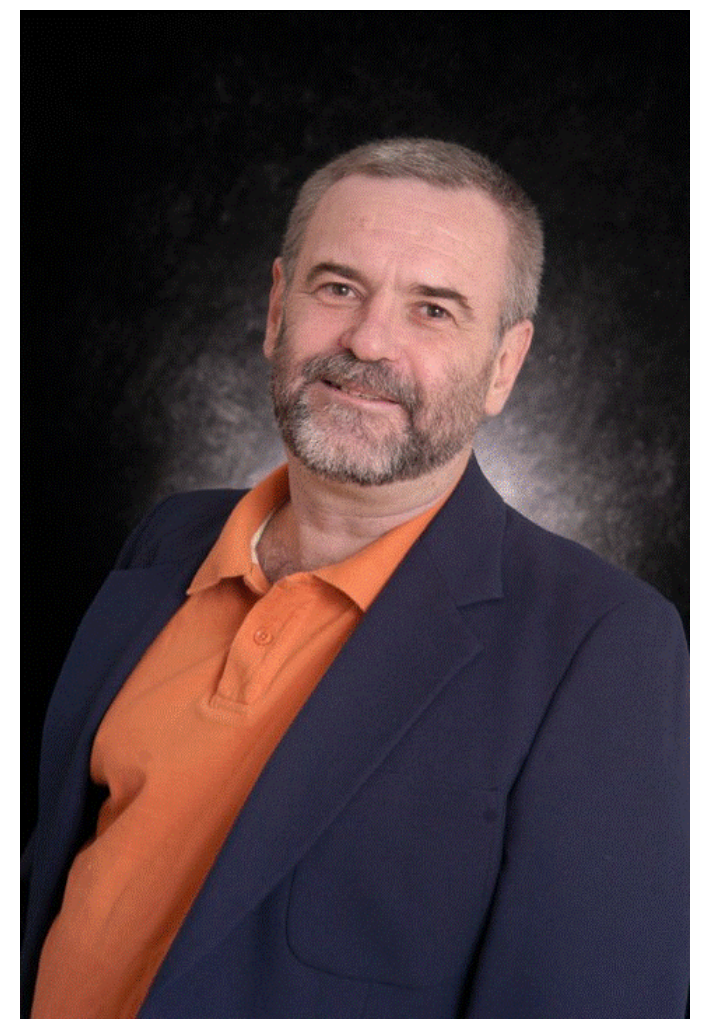

Figure 2. OLE's CEO Dr. Nigel Spence.

OLE guarantees that documents are edited by experts who are native English speakers, most with a PhD (Figure 3) and all with many years of research or professional experience, and expertise covering a wide range of academic and research disciplines. OLE specializes in journal submissions but handles documents of all types, including research papers and abstracts, conference presentations, referees' reports, responses to referees' reports, educational and teaching materials, CVs, newsletter articles, annual reports, proposals, submissions, and even personal letters.

OLE can also tailor a cover letter for submission with a document, help with responding to reviewer comments, and even select a journal. OLE offers a quality guarantee and works with clients to try to ensure that they are fully satisfied. OLE's quality assurance system is compliant with ISO 9001:2015.

On request, OLE is happy to provide a signed certificate indicating that a particular document has been edited by qualified native English speakers.

If a department or institution appoints OnLine English as its preferred provider of editorial services, OLE's Preferred Provider Program offers exclusive benefits, by providing a further $5 \%$ discount on all orders for regular "Gold" and premium "Platinum" editing services placed by the department or institution, and by providing journal selection and cover letter services, when requested, at no additional charge. In return, OLE asks that all document editing for the faculty and students is placed exclusively with OnLine English to receive their world-class editorial support. 


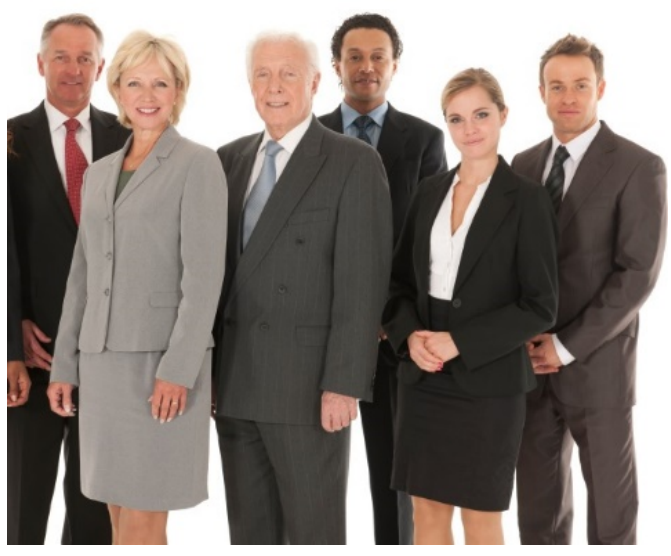

Figure 3. OnLine English editors.

For scientists and professionals who have English as a second language, the OnLine English service should be seen as an investment in saving time and improving the presentation of their research articles and business documents. OLE is committed to providing its clients with an excellent return on this investment.

To submit a document for editing or to obtain further information about the OnLine English service, please visit the website https://www.oleng.com.au or contact OLE by email at ole@oleng.com.au.

\section{Conclusion}

Today, English is the main language of international scientific and humanities communication. The presentation of written texts in high-quality English is necessary in all branches of science and in everyday life. The use of qualified editors has been common in many universities and institutions. For academic authors who have English as a second language, specialized services such as OLE save time and improve the chances of their papers being accepted and published by journals.

\section{Conflicts of Interest}

The authors declare no conflicts of interest regarding the publication of this paper.

\section{References}

[1] Holy Bible, King James Version (2010). Zondervan.

[2] Brondz, I. (2012) Analytical Methods in Quality Control of Scientific Publications. American Journal of Analytical Chemistry, 3, 443-447. https://doi.org/10.4236/ajac.2012.36058

[3] Brondz, I. (2013) Analytical Methods in Quality Control of Scientific Publications Part II: The Authors', Reviewers', Editors' Responsibility and the Publishers' Authority. International Journal of Analytical Mass Spectrometry and Chromatography, 1, 81-89. https://doi.org/10.4236/ijamsc.2013.12010

[4] Brondz, I. (2014) Analytical Methods in Quality Control of Scientific Publications 
Part III: Publishers' Ethics and Editors' Complicity. International Journal of Analytical Mass Spectrometry and Chromatography, 2, 77-102. https://doi.org/10.4236/ijamsc.2014.23008

[5] Brondz, I. (2014) Analytical Methods in Quality Control of Scientific Publications Part IV: Fraud Ordered by the Pharmaceutical Industry. International Journal of Analytical Mass Spectrometry and Chromatography, 2, 103-112. https://doi.org/10.4236/ijamsc.2014.24009

[6] Brondz, I. (2015) Analytical Methods in the Quality Control of Scientific Publications Part V: The Fraud of Pseudoscientists Based on False Measurements and Method Development. International Journal of Analytical Mass Spectrometry and Chromatography, 3, 25-31. https://doi.org/10.4236/ijamsc.2015.32003

[7] Brondz, I. (2019) Analytic Methods for Quality Control of Scientific Publications Part VI: Presentation in Research Gate, Journal Indexing, and Recognition. International Journal of Analytical Mass Spectrometry and Chromatography, 7, 37-44. https://doi.org/10.4236/ijamsc.2019.74005

[8] Brondz, I. (2019) Research Gate (RG) Is a Meeting Point for Progress in Chemical Knowledge. International Journal of Analytical Mass Spectrometry and Chromatography, 7, 35-36. https://doi.org/10.4236/ijamsc.2019.73004

[9] Brondz, I. (2019) Analytic Methods for Quality Control of Scientific Publications Part VI: Presentation in Research Gate, Journal Indexing, and Recognition. International Journal of Analytical Mass Spectrometry and Chromatography, 7, 37-44. https://doi.org/10.4236/ijamsc.2019.74005 